DOI: $10.15290 /$ bsl.2018.13.18

\title{
Weronika Biegluk-Leś
}

Wydział Filologiczny

Uniwersytet w Białymstoku

e-mail: w.les@uwb.edu.pl

ORCID: 0000-0003-3596-1357

\section{Zamknięcie w języku. Oblężenie Jewgienija Griszkowca}

Granice mego języka oznaczają granice mego świata.

Ludwig Wittgenstein ${ }^{1}$

Kiedy pod koniec lat 90. ubiegłego wieku Jewgienij Griszkowiec debiutuje na moskiewskich scenach jako dramaturg i aktor monodramem Jak zjadłem psa (Как я съел собаку 1998) ${ }^{2}$, który przynosi mu sympatię i uznanie widzów oraz wywołuje konsternację w środowisku zawodowców ${ }^{3}$, ma już za sobą pewne doświadczenia teatralne w swoim rodzinnym Kiemierowie jako założyciel studenckiego teatru Loża. Loża, utworzona w 1990 roku $^{4}$, szybko

\footnotetext{
${ }^{1}$ L. Wittgenstein, Tractatus logico-philosophicus, przeł. i wstępem opatrzył B. Wolniewicz, Warszawa 2000, s. 64 .

2 Monodramy i sztuki Jewgienija Griszkowca goszczą z powodzeniem na scenach polskich teatrów od 2001 roku. Polscy widzowie mogli obejrzeć m.in. Jak zjadłem psa, Jednocześnie, Miasto, Zimę czy Planetę. Więcej na ten temat zob. np.: I.A. NDiaye, O specyfice kulturowo-językowej monodramu Jewgienija Griszkowca "Jak zjadtem psa" i potencjalnych oraz realnych reperkusjach przekładowych z uwzględnieniem tłumaczenia na język polski, „Acta Neophilologica” 2016, t. 18, nr 2, s. 168-169. Daty podane przy tytułach sztuk, tu i dalej, dotyczą premierowych spektakli.

3 Wioletta Gudkowa twierdzi, że szok, który „przynosi ze sobą” Griszkowiec, mimo że rewolucyjny w swojej istocie, zostaje ujęty w inteligentną formę [zob. V. Gudkova, Teatr i mneniâ Evgeniâ Griškovca, w: Pro scenium. Voprosy teatra, izd. vtoroe, ispr., sost. i otv. red. V.A. Maksimova, Moskva, 2007, s. 64].

4 Zob. np. M.I. Gromova, Russkâ̂ dramaturgiâ konca XX - načalo XXI vv., Moskva 2009, s. 335.
} 
przerodziła się w samodzielny teatr, w którym na przestrzeni siedmiu lat (1991-1998) Griszkowiec testował wizję teatru opartego na improwizacji ${ }^{5}$, aktywnym kontakcie z widzem, wykorzystującego gest sceniczny (elementy pantomimy), aby potem, już samodzielnie, rozwijać i prezentować swój „teatr intymny" ${ }^{6} \mathrm{~W}$ autorskich spektaklach - monodramach. Oprócz debiutanckiego („kultowego" już) Jak zjadłem $p s a^{7}$, na początku XXI wieku pojawiają się: Jednocześnie (ОдноврЕмЕнно 2001), Planeta (Планета 2001), Drednouty (Аредноуть 2002), ugruntowując pozycję Griszkowca jako „króla monospek-

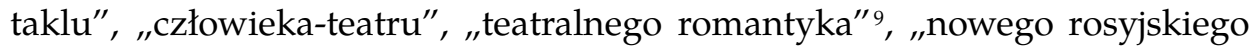
sentymentalisty"10, "absolutnego subiektywisty" czy "dramaturga naiwnego"11. Równolegle zaczynają pojawiać się "sztuki w formie dialogów"12

5 Margarita Gromowa podkreśla, że w teatrze Loża Griszkowiec preferował pracę z tekstami niegotowymi („незафиксированными”) oraz stosował zasadę zespołowej „improwizacji na temat". Zadanie aktorów nie polegało na nauczeniu się gotowego tekstu, ale wypowiedzeniu go „od siebie" [M. Gromova, Russkaâ dramaturgiâ..., s. 335].

6 Tak określili specyfikę teatru Griszkowca w artykule, który ukazał się w 2008 roku, Mark Lipowiecki i Birgit Beumers - M. Lipoveckij, B. Bojmers, Travma-performans - identičnost': intimnyj teatr Evgeniâ Griškovca, w: SSSR: territoriâ lûbvi. Sbornik statej. (Novye materialy i issledovaniâ po istoriirusskoj kul'tury, Vyp. 6), red.-sost. N. Borisova, K. Bogdanov, Û. Murašov, Moskva 2008, s. 233.

7 Walenty Piłat nazywa tę sztukę „,najsłynniejszym monodramem we współczesnej dramaturgii rosyjskiej” - W. Piłat, Monodram we wspótczesnej dramaturgii rosyjskiej, „Acta Neophilologica” 2015, t. 17 , nr 1, s. 145.

8 Należy podkreślić, że w kwestii klasyfikacji Planety badacze nie są zgodni, np. Mark Lipowiecki, Birgit Beumers czy Swietłana Gonczarowa-Grabowska określają ją jako monodram, zaś Margarita Gromowa charakteryzuje jako pierwszą sztukę, która wychodzi poza ramy monodramu w kierunku "sztuk w formie dialogów” [zob. M. Lipoveckij, B. Bojmers, Travma..., s. 235; S.Â. Gončarova-Grabovskaâ, Monodrama v tvorčestve E. Griškovca, "Vesnìk BDU”, seria 4, 2009, nr 3, s. 27; M.I. Gromova, Russkaâ dramaturgiâ..., s. 347].

9 Zob. np.: M.I. Gromova, Russkaâ dramaturgiâ..., s. 333; O.S. Naumova, Problema teatral'nogo sinkretizma v tvorčestve E. Griškovca, w: Sovremennaâ russkaâ drama, Kazan' 2008, s. 80.

10 Ta formuła (autorstwa samego dramaturga) okazała się szczególnie inspirująca dla polskich badaczy twórczości Jewgienija Griszkowca. Zob. np.: L. Mięsowska, Jewogienij Griszkowiec "nowy sentymentalista" rosyjskiej dramaturgii przełomu XX $i$ XXI wieku, w: Tradycje i nowatorstwo w kulturach i literaturach stowianskich, red. I. Kowalska-Paszt i in., Szczecin 2004; W. Piłat, Teatr "nowego sentymentalizmu” Jewginija Griszkowca i jego polskie interpretacje, „Acta Polono-Ruthenica” 2005, t. 10; K. Syska, Nowa sentymentalność. Przejawy świadomości konwergencyjnej w wybranych monodramach Jewogienija Griszkowca, „Przegląd Rusycystyczny” 2013, nr 2. Przywoływana już Iwona NDiaye nazywa teatr Griszkowca "groteskowo-sentymentalnym" [I.A. NDiaye, O specyfice kulturowo-językowej..., s. 169].

11 Zob. np.: I. Bolotân, Griškovec: avtor, fenomen, sindrom, „Literaturnaâ Rossiâ” 2006, nr 42, https://litrossia.ru/item/1263-oldarchive/, [dostęp 21.05.2017].

12 Określenie Margarity Gromowej, która dokonuje gatunkowej klasyfikacji dramatów Griszkowca. Zob. M.I. Gromova, Russkâ̂ dramaturgiâ..., s. 347. 
- Zapiski rosyjskiego podróżnika (Записки русского путешественника 1999) Zima (Зима 2000), Miasto (Город 2001) i inne.

Próbując określić swoistość autorskiego teatru Griszkowca badacze i krytycy koncentrują się głównie na jego monodramach, ponieważ to przede wszystkim one przesądziły o fenomenie, jakim stały się dla rosyjskiego teatru końca XX - początku XXI wieku spektakle autora +1 :

его моноспектакли, и прежде всего „Как я съел собаку”, создали новую эстетическую конвенцию - новый тип отношений между драматургом и актером, между театром и зрителем, между автором и языком. Иными словами - новую интонацию ${ }^{13}$.

Istotą owej nowej intonacji, „skromnej i nienachalnej”, staje się ukierunkowanie na bezpośredni kontakt $\mathrm{z}$ widzem ${ }^{14}$, zaś ważnymi składowymi maksymalna otwartość i szczerość. Zdaniem Pawła Rudniewa to właśnie takie cechy indywidualnej, „skrajnie egocentrycznej” wypowiedzi Griszkowca, jak: konfesyjność (ruch „od Ja”, „od serca”), odważne demonstrowanie widzowi swoich duchowych traum, naiwność i oczekiwanie współczucia, uczyniły jego twórczość ważnym kulturowym zjawiskiem końca lat $90^{15}$. Wyrazistość i niepowtarzalność osobowości scenicznej, którą kreował w swoich monodramach, spowodowała, że niektórzy badacze stwierdzali wręcz, że najlepiej spektakle Griszkowca tworzy, gra i wyjaśnia sam Griszkowiec ${ }^{16}$. "Polifunkcjonalność" 17 - umiejętność harmonijnego zintegrowania funkcji aktora, twórcy tekstu, scenografa i reżysera spektaklu - problematyzuje granicę między realnym człowiekiem a postacią sceniczną, niejako automatycznie otwierając zarówno perspektywę meta-, jak i pole gry z nią. Synkretyzm, charakteryzujący monodramy "człowieka z Kiemierowa”, staje się bowiem

13 ,jego monospektakle, przede wszystkim Jak zjadłem psa, stworzyły nową konwencję estetyczną - nowy typ relacji między dramaturgiem a aktorem, między teatrem a widzem, między autorem a językiem. Innymi słowy - nową intonację" [M. Lipoveckij, B. Bojmers, Travma - performans - identičnost' ..., s. 234]. Wszystkie tłumaczenia w artykule, jeśli nie zaznaczono inaczej, moje [W.B.L.].

14 Lipowiecki i Beumers nazywają to „iluzją bezpośredniego kontaktu” [M. Lipoveckij, B. Bojmers, Travma ..., s. 234] bądź „iluzją szczerej wypowiedzi”, wskazując, że w dramaturgii Griszkowca staje się ona swoistym chwytem artystycznym [M. Lipoveckij, B. Bojmers, Performansy nasiliâ: literaturnye i teatral'nye èksperimenty "novoj dramy", Moskva 2012, s. 120].

15 P. Rudnev, Drama pamâti. Očerki istoriirossijskoj dramaturgii. 1950-2010-oe, Moskva 2018, s. 308.

16 V. Gudkova, Teatr i mneniâ Evgeniâ Griškovca...., s. 58. Por. też I. Bolotân, Griškovec: avtor, fenomen, sindrom..., [dostęp 21.05.2017].

17 O „polifunkcjonalności” autora jako jednym z przejawów synkretyzmu współczesnego dramatu rosyjskiego zobacz np. O. Naumova, Problema teatral'nogo sinkretizma..., s. 81. 
synkretyzmem ontycznym, w którym krzyżują się pojęcia i zjawiska przynależące do różnych płaszczyzn (fikcja - rzeczywistość, twórca - dzieło, autor bohater, chwyt - wyznanie itd.). Ze szczególną wyrazistością przejawiają się takie chwyty - uznawane za metateatralne ${ }^{18}$ - jak mise en abyme czy też bezpośredni zwrot postaci do widza/czytelnika. Mnożenie poziomów rzeczywistości, granica między którymi ulega rozmyciu, zderza się w autorskim teatrze Griszkowca z formułą „autentyczności” przeżycia i szczerości wyznania, wspomaganej przez autobiografizm.

Zrozumiałe, że skupienie się na sposobie kreowania postaci scenicznej przez Griszkowca - reżysera, autora - pociągnęło również za sobą refleksję nad pojmowaniem przez niego roli aktora, nad formułowaniem koncepcji gry aktorskiej. Część badaczy twierdzi, że w centrum teatru Griszkowca znajduje się całkowicie tradycyjna aktorska metamorfoza ${ }^{19}$ - aktor „wciela się w postać", „wchodzi w rolę". Inni z kolei uważają, że autor Planety raczej prowokuje aktora do "opowiedzenia siebie":

Гришковец пытается не „дать свои слова другим", а стремится подтолкнуть актеров, т.е. тех, чьей профессией стало заучивание готового текста, освоение мыслей и чувств чужого, к „акту личной искренности" (Гротовский), выразить собственный опыт ${ }^{20}$.

18 Zob. np. K. Ruta-Rutkowska, Metateatralne gry w dramacie wspótczesnym na przykładzie twórczości Mariana Pankowskiego, „Pamiętnik Literacki” 2000, z. 4, s. 125-153.

19 Por. D. Bykov, Vzroslaâ žizn' molodogo čeloveka, "Novyj mir" 2002, nr 1, https://magazines. gorky.media/novyi_mi/2002/1/vzroslaya-zhizn-molodogo-cheloveka.html, [dostęp 7.03.2018]; O. Naumova, Problema teatral'nogo sinkretizma v tvorčestve E. Griškovca, w: Sovremennaâ rossijskâa drama, Kazan' 2008, s. 65.

20 „Griszkowiec nie stara się «dać swoje słowa» innym, ale dąży do tego, aby skłonić aktorów, tzn. tych, których profesją stało się wyuczenie gotowego tekstu, przyswojenie sobie myśli i uczuć obcego, do «aktu osobistej szczerości» (Grotowski), wyrażenia własnego doświadczenia" [V. Gudkova, Teatr i mneniâ Evgeniâ Griškovca..., s. 65]. Rzeczywiście, kiedy czyta się wypowiedzi Griszkowca o tym, że mówiąc swój tekst na scenie nie improwizuje, ale za każdym razem tworzy go - tu i teraz, wypowiedzi, w których wyjaśnia, że gra staje się dla niego procesem życia, teatrem, rozumianym jako chwilowe przeżywanie [zob. np. I. Ševelev, Teatr i žizn' russkogo putešestvennika. Interv'û s Evgeniem Griškovcom, „Vremâ" MN 8 августа 2001, http:// www.litkarta.ru/dossier/shevelev-grishkovets-interview/dossier 7455/, [dostęp 12.06.2017] przypominają się poszukiwania twórcze Jerzego Grotowskiego. Twórca Teatru 13 Rzędów i Laboratorium charakteryzując ",akt całkowity” utożsamia grę aktora z "penetrowaniem obszarów własnego doświadczenia”, "odkrywaniem siebie” [zob. np. J. Grotowski: Teatr a rytuał, w tegoż: Teksty zebrane, red. A. Adamiecka-Sitek i in., Warszawa 2012, s. 367-368]. Yan Michalski stwierdza, że w teatrze Grotowskiego: „Aktor staje się nie tylko interpretatorem postaci stworzonej przez dramaturga, staje się także tłumaczem samego siebie, tego, co najbardziej intymne i ukryte w głębi jego istoty". Ten brazylijski krytyk teatralny polskiego pochodzenia tak pojmowaną grę aktorską nazywa "striptizem emocjonalnym” [Y. Michalski, Grotowski - mnich poszukiwań teatralnych, http://www.grotowski.net/performer/performer-6/grotowski-mnich- 
Ponieważ dla Griszkowca niezwykle istotne jest nawiązanie kontaktu z publicznością ${ }^{21}$, "bycie usłyszanym”, uniwersalizuje on to, co indywidualne, łącząc konfesyjny, intymny charakter dyskursu swojego bohatera z tym, co bliskie i znane każdemu widzowi:

Он сумел слиться с каждым из зрителей и в то же время остаться самим собой. Передать на сцене поэзию обыденности. Воплотить неповторимую типичность. Заставить почувствовать, что между моряками, учеными, студентами, учителями, лицедеями - в общем, всеми нами нет никаких гранищ ${ }^{22}$.

Stąd też nic dziwnego, że jego monodramy odwołują się do zbiorowej pamięci Rosjan, stając się, jak zauważa na przykład Iwona NDiaye, "tragikomiczną medytacją" na temat zwykłego, codziennego dnia, znanych i lubianych rosyjskich piosenek, popularnej sałatki sylwestrowej, służby wojskowej w marynarce czy podróży koleją transsyberyjską ${ }^{23}$. Griszkowiec odkrywa, zdaniem Pawła Rudniewa, "technologię wspominania kolektywnego", która, jak podkreśla badacz, okazała się niezwykle przydatna na wczesnym etapie formowania się nowej, postradzieckiej rzeczywistości, ponieważ oferowała

poszukiwan-teatralnych, [dostęp 12.06.2017]. Z kolei rosyjski teatrolog i krytyk Paweł Rudniew charakteryzując dyskurs bohatera monodramów Griszkowca używa określenia „swoisty ekshibicjonizm słowny, słowne porno" [P. Rudnev, Drama pamâti..., s. 309].

21 Halina Mazurek stwierdza wręcz, że: „opowiadanie Griszkowca nie odbywa się bez publiczności, co jest jego głównym założeniem, celem i istotą" [H. Mazurek, Oblicza monodramu w nowej dramaturgii rosyjskiej, "Studia Słowianoznawcze” 2015, t. 11, s. 237].

22 „Był w stanie zlać się z każdym z widzów, pozostając przy tym sobą. Przekazać na scenie poezję codzienności. Wcielić niepowtarzalną typowość. Zmusić do odczucia, że między marynarzami, uczonymi, studentami, nauczycielami, działaczami - ogólnie rzecz biorąc między nami wszystkimi nie ma granic" [M. Davydova, Konec teatral'noj èpohi, Moskva 2005, s. 219]. Por. też: „Bohater Griszkowca, rzeczywiście, mówi tylko o swoim, ale żeby być zrozumianym przez wszystkich, nadaje temu «uniwersalny kształt»" [I. Bolotân, Griškovec: avtor, fenomen, sindrom..., [dostęp 21.05.2017]; „,W swoich spektaklach [...] on był w stanie połączyć elitarność i powszechność, wyrafinowanie i prostotę" [S. Evrosinin, Aktual'noe odinočestvo Evgeniâ Griškovca, „Novyj mir" 2006, nr 11, https://magazines.gorky.media/novyi_mi/2006/11/aktualnoe-odinochestvoevgeniya-grishkovcza.html, dostęp 5.06.2017]. Zob. też wypowiedzi samego dramaturga Coraz rzadziej mówię „ja”. Rozmowa z J. Griszkowcem, „Dialog” 2000, nr 12, s. 111-122.

23 I.A. NDiaye, O specyfice kulturowo-językowej..., s. 167. Dmitrij Abaulin również podkreśla ową umiejętność Griszkowca eksponowania na pozór mało istotnych „odprysków życia codziennego", które w efekcie "łączą nas bardziej niż idee" [D. Abaulin, Griszkowiec ante portas, „Dialog" 2002, nr 5-6, s. 220]. Por. też: „Sztuki Griszkowca [...] są historią nie tylko wspó1czesnego człowieka, zawieszonego w przestrzeni ponad granicami kulturowymi, etnicznymi czy społecznymi. Są także opowieścią o współczesnej Rosji [...]" [L. Mięsowska, Między postkomunizmem a postmodernizmem. Najnowszy dramat rosyjski w poszukiwaniu tożsamości kulturowej, „Miscellanea Posttotalitariana Wratislaviensia” 2016, nr 4, s. 69]. 
możliwość: „вспоминать прошлое, латая дыры истории: концентрация «хорошей» памяти - в мире детства, «плохой» памяти в репрессивных институциях: армии и школе [...]"24.

Chociaż ostatnimi czasy badacze dość zgodnie obwieścili „wyczerpanie się" Griszkowca-dramaturga ${ }^{25}$, to, także niemal jednogłośnie, przyznają, że autor Zimy, zanim odszedł, by realizować się w innych obszarach sztuki ${ }^{26}$, odcisnął istotny ślad na rodzimej dramaturgii i sztuce teatralnej. Podkreślają jego zasługi w reaktywacji i rozwoju monodramu ${ }^{27}$, mówią o wprowadzeniu nowej, zorientowanej na widza, formuły kontaktu z publicznością ${ }^{28}$.

Należy zauważyć, że dramaty Griszkowca, zanim uzyskały swój kształt „ostateczny" (zostały opublikowane), funkcjonowały w świadomości krytyków, badaczy i widzów jako konkretyzacje sceniczne - spektakle. Dlatego też wiele prac analizujących specyfikę poszczególnych sztuk dramaturga odwołuje się także do ich określonej realizacji na scenie. Niektórzy badacze uważają wręcz analizę spektakli Griszkowca za konieczny punkt wyjścia do wszelkich badań nad jego twórczością dramaturgiczną ${ }^{29}$.

Sztuka Oblężenie (Ocaða) również przez długi czas istniała w "nieukonstytuowanej" formie. Pierwsze inscenizacje, sięgające początków teatralnej działalności Griszkowca (teatr Loża), były de facto zespołowymi improwizacjami na podstawie "luźnego", "szkicowego" scenariusza. Ogromną rolę w krystalizacji ostatecznej wersji dramatu miało wystawienie sztuki w Moskwie na Małej Scenie teatru MCHAT im. Czechowa w 2003 roku $^{30}$. Analiza dramatu $\mathrm{w}$ niniejszym artykule opiera się na tekście opublikowanym w 2011 roku $^{31}$.

\footnotetext{
24 „wspominać przeszłość, łatając dziury historii: koncentracja «dobrej» pamięci - w świecie dzieciństwa, «złej» pamięci - w opresyjnych instytucjach: w armii i w szkole" [P. Rudnev, Drama pamâti, s. 308].

25 I. Bolotân, Griškovec: avtor, fenomen, sindrom..., [dostęp 21.05.2017]; P. Rudnev, Drama pamâti, s. 305.

26 Jako pisarz - autor powieści i opowiadań, członek zespołu muzycznego, aktor filmowy...

27 Zob. np. S.Â. Gončarova-Grabovskaâ, Monodrama v tvorčestve E. Griškovca, s. 26-31.

28 Niektórzy badacze twierdzą wręcz, że od Griszkowca rozpoczyna się "nowy dramat” w Rosji [M. Lipoveckij, B. Bojmers, Travma..., s. 117].

29 Zob. np.: J. Gracla, Jewogienij Griszkowiec: autor, aktor, twórca, w: Artysta. Biokulturowy interfejs?, red. M. Pieniążek, Kraków 2017, s. 56-65.

30 M. Lipoveckij, B. Bojmers, Performansy nasiliâ: literaturnye i teatral'nye èksperimenty "novoj dramy", Moskva 2012, s. 154.

31 E. Griškovec, Satisfakciâ. Scenarij, p'esy ilirika, Moskva 2011. Dalej wszystkie cytaty z tekstu według tego wydania, numer strony w nawiasie po cytacie. W Polsce sztuka była wystawiana w krakowskim teatrze Bagatela w 2011 roku w reżyserii Małgorzaty Bogajewskiej. Tłumaczenia dramatu na potrzeby spektaklu dokonała Agnieszka Lubomira Piotrowska. Znamienne,
} 
Należy zauważyć, że Oblężenie to sztuka nietypowa w dorobku autora Zapisków rosyjskiego podróżnika, już chociażby ze względu na „odejście od monologicznej formy" oraz "inne podejście do problemu traumy" ${ }^{32}$.

Osnowa dramatu Griszkowca - jego "tkanka” - ma charakter intertekstualny. Tworzy ją wariacja na temat Iliady Homera, a dokładniej - oblężenia Troi. Wokół tego centralnego dla sztuki motywu rozwijają się, opowiedziane "od nowa", historie z greckiej mitologii ${ }^{33}$. Specyfika tekstu z jednej strony nawiązuje do tradycji dramatu antycznego, w którym widz nie oczekiwał nowości tematycznej, ale delektował się nowym sposobem interpretacji, przedstawienia doskonale mu znanych historii ${ }^{34}$, z drugiej zaś strony - łączy tę tradycję z (charakterystyczną dla dramatu postmodernistycznego) strategią szeroko rozumianej gry, dekonstrukcją kulturowych mitów, symboli, utrwalonych i uznanych prawd.

W Oblężeniu rozwijają się równolegle, nawzajem się dopełniając, trzy wątki fabularne: „Zwykłe” i „ważne” historie opowiadane przez Weterana Chłopakowi, rozmowy i działania trójki wojowników oblegających miasto (Troję) oraz uporczywie podejmowane przez Ikara próby wzbicia się w powietrze. Warto podkreślić, że wątek Ikara realizuje się jako "czyste” działanie. Próby oderwania się od ziemi odbywają się w milczeniu i samotności. Ikar nie wchodzi w żadne bezpośrednie interakcje $\mathrm{z}$ innymi bohaterami sztuki (nie licząc gestu powitania skierowanego ku wojownikom). Wszystko to powoduje, że milczące sceny z jego udziałem stają się swoistym kontrapunktem dla pozostałych - zanurzonych w słowie - partii dramatu, wymownym ko-

że w swojej interpretacji Oblężenia Bogajewska konkretyzuje uniwersalność poruszanej przez dramaturga problematyki, osadzając ją w "swojskich klimatach”: „To jest sztuka o naszych polskich przywarach i przyzwyczajeniach." - stwierdza reżyserka w wypowiedzi, zamieszczonej na stronie teatru, https://www.bagatela.pl/spektakl/oblezenie, [dostęp 14.03.2018]. Por. też recenzję spektaklu Łukasza Maciejewskiego: „Griszkowiec pisał o Rosji, ale w Krakowie oglądamy również satyryczny portret Polski zwaśnionej, w której kłócimy się po to, żeby się kłócić; godzimy, żeby godzić. Nie ma w tym sensu, scalającej konstrukcji. Jest pusty śmiech. A to Polska właśnie" [Ł. Maciejewski, Śmiesznie i strasznie bywa w teatrze Bagatela, "Gazeta Krakowska" 30 listopada 2011, http://www.dziennikteatralny.pl/artykuly/smiesznie-i-strasznie-bywa-w-tea trze-bagatela.html, dostęp 2.03.2018].

32 Sposób artykulacji traumy powstałej w wyniku zderzenia jednostki z opresyjną, brutalną rzeczywistością jest jednym z głównych "kluczy” interpretacyjnych twórczości Griszkowca, który stosuje w swoich pracach Mark Lipowiecki. Więcej na ten temat zob. M. Lipoveckij, B. Bojmers, Performansy nasiliâ..., s. 154.

33 „Oblężenie prezentuje swoistą postmodernistyczną grę, tekstową i kompozycyjną, w opowiadanie znanych fabuł po swojemu" [M. I. Gromova, Russkaâ dramaturgiâ konca XX - načalo XXI vv., Moskva 2009, s. 356].

34 W sztuce „nie zobaczymy” też scen drastycznych, zostaną one jedynie pośrednio zasygnalizowane, jak np. śmierć jednego z wojowników w bitwie. 
mentarzem do wysiłków czynionych przez nich przede wszystkim w sferze oratio, nie actio.

Brak formalnych wyznaczników poszczególnych części dramatu (nie ma podziału na sceny czy akty). Dystynktywną funkcję spełniają didaskalia oraz odpowiednie wykorzystanie światła, muzyki i przestrzeni scenicznej. Uwagi odautorskie kreują ową przestrzeń minimalistycznie ${ }^{35}$, operując pojedynczymi znaczącymi elementami, takimi jak: wysoki maszt okrętowy pośrodku sceny, ruiny antycznej budowli i morze za nimi - w głębi, za kurtyną. Takie konstruowanie przestrzeni jednocześnie kondensuje znaczenie określających jej specyfikę detali, jak i „otwiera", uniwersalizuje ich wymowę. Na przykład, maszt okrętowy stopniowo, w miarę rozwoju wydarzeń, wywołuje szereg asocjacji, budując siatkę znaczeń odsyłającą do czytelnych, zbanalizowanych - chciałoby się rzec - toposów i literackich obrazów: bohaterowie znajdują się na okręcie, podróżują, życie jest podróżą, a statek figurą ludzkiego losu, podróż Odyseusza jako tułaczka w poszukiwaniu domu, każdy człowiek poszukuje swojego miejsca, „,każdy z nas jest Odysem, co wraca do swej Itaki..." ${ }^{36}$. Kreacja przestrzeni koncentruje też uwagę widza (czytelnika) na wypowiadanym przez bohaterów słowie, ono bowiem odgrywa w sztuce kluczową rolę.

Griszkowiec gra kreowaną w dramacie czasoprzestrzenią. Jej specyfika konstytuuje się na styku bezczasowej uniwersalności, właściwej mitycznej opowieści archetypowości oraz współczesności kreowanej dzięki leksyce i technicznym artefaktom (telefon komórkowy, megafon). Próżno szukać zatem $\mathrm{w}$ tej sztuce tradycyjnie rozumianej chronologii. Rozwijające się niezależnie od siebie i ukazywane na przemian wątki aktualizują bowiem zarówno sytuację po zdobyciu Troi (Weteran od samego początku mówi o oblężeniu w czasie przeszłym, a pod koniec spotkania przyznaje wprost, że to on wymyślił, jak zwyciężyć dzięki fortelowi z „ogromnym drewnianym koniem"), jak i jej bezskuteczne obleganie (trzej wojownicy u bram). Znamienne, że w finale dramatu obie płaszczyzny łączą się dzięki spotkaniu bohaterów. Weteran, znużony i rozczarowany rozmową, przywołuje na scenę swoich towarzyszy broni - trzech wojowników oblegających Troję. Również w obrębie poszczególnych wątków nie możemy mówić o jednorodności czasowej. Zarówno ponadczasowość, jak "starożytność” (wojowie mają na sobie antyczne kostiumy) kreowanych przestrzeni jest permanentnie naruszana przez język

35 Por. D. Bykov, Vzroslaâ žizn' molodogo čeloveka, „Novyj mir” 2002, nr 1, https://magazines. gorky.media/novyi_mi/2002/1/vzroslaya-zhizn-molodogo-cheloveka.html, [dostęp 7.03.2018].

36 L. Staff, Odys, https://poezja.org/wz/Staff_Leopold/1564/Odys, [dostęp 7.02.2018]. 
postaci, nasycony określeniami związanymi z różnymi sferami cywilizacji współczesnej, m.in. wojskowością, nauką i techniką (dyslokacja, celafon, porolon ${ }^{37}$ ), pojawiają się także odniesienia do literatury rosyjskiej czy kultury masowej (np. fragmenty nieoficjalnego hymnu rosyjskich kosmonautów piosenki Nadzieja, którą wykonywała m.in. Anna German). Niebagatelną rolę w uwspółcześnieniu dyskursu odgrywa również język potoczny ${ }^{38}$. Z perspektywy kompozycji całego utworu takie „współistnienie” w warstwie fabularnej oraz językowej dramatu "teraźniejszości” $\mathrm{i}$ „przeszłości” (a z punktu widzenia odbiorcy także „pozaczasowej uniwersalności”) generuje złożoną, jednocześnie historyczną i ahistoryczną, czasoprzestrzeń gry - gry dekonstruującej „kanoniczność” mitycznych historii, obnażającej indolencję języka jako narzędzia komunikacji i opisu świata, problematyzującej tradycyjne "taktowanie" czasu. W jednej z końcowych scen Oblężenia Odyseusz pogrąży się w rozważaniach:

то, что сейчас происходит, это сейчас, а потом оно превращается в раньше. ГАе между „сейчас" и „раньше"? [...] Где этот переход от „сейчас" к „раньше", понимаешь? [s. 155].

[to, co teraz się dzieje, to jest teraz, a potem ono przekształca się we wcześniej. Gdzie jest między "teraz" a „wcześniej"? Gdzie jest to przejście od „teraz” do „wcześniej”?]

Podobne kwestie związane z naturą czasu będą nurtować również innego bohatera sztuki - Achillesa (Trzeciego wojownika):

есть год, есть месяц, есть день, есть час, есть минута, есть секунда. И эти секунды надо считать так: один и, два и, три и, четыре и... Вот это „и” это интервал между секундами. [...] Как узнать самое маленькое „и”? И с точки зрения этого самого маленького „и“, что такое время? [s. 141].

[jest rok, jest miesiąc, jest dzień, jest godzina, jest minuta, jest sekunda. I te sekundy należy liczyć tak: jeden i, dwa i, trzy i, cztery i... Właśnie to „i" jest interwałem pomiędzy sekundami. Jak rozpoznać najmniejsze „i"? I z punktu widzenia tego najmniejszego „i", czym jest czas?]

Niejednorodny jest również charakter postaci. Wstępnie możemy je podzielić na dwie grupy: tych, którzy posiadają imię (Ikar) i tych, których nazwa uosabia pewne cechy, funkcje, postawy. Synteza konkretu i uniwersalności, cechująca mitologiczną narrację spotyka się w Oblężeniu ze schema-

\footnotetext{
$37 \mathrm{~W}$ rosyjskim określenie elastycznego poliuretanu (pianki poliuretanowej).

38 Na przykład w wypowiedzi Chłopaka pojawiają się określenia: „прогоняет какую-то свою тему" ('nawija na jakiś swój temat'), „влип я" ('wpadłem') itd.
} 
tycznym modelowaniem postaci (bohater everyman, bohater-model), odsyłającym np. do specyfiki bohatera dramatu ekspresjonistycznego. Na pierwszy rzut oka typizująco-uogólniające określenia protagonistów Oblężenia (Weteran, Chłopak, Pierwszy wojownik, Drugi wojownik, Trzeci wojownik, Bogini) pozbawiają ich indywidualności. W miarę rozwoju "opowieści" stopniowo odsłaniają się jednak ich "prawdziwe” oblicza, np. Weteran okazuje się być Odyseuszem, zaś Trzeci wojownik - Achillesem. Pojawiająca się kilkakrotnie $\mathrm{w}$ sztuce Bogini także niejedno ma imię. Wciągając na maszt chorągiewkę $\mathrm{z}$ wizerunkiem słońca na początku dramatu i opuszczając ją $\mathrm{w}$ finale staje się Eos/Jutrzenką - rozpraszającą mroki nocy boginią zorzy porannej (tym bardziej, że efektem tych działań dla widza jest oświetlenie sceny i jej zaciemnienie). W momencie, kiedy wręcza Drugiemu wojownikowi przed bitwą strzałę (jak się później okazuje - zapowiedź śmierci na polu walki) staje się Nike, boginią zwycięstwa. Taka konstrukcja postaci wzmacnia metateatralny wymiar Oblężenia, korespondując z ontologią wykreowanego $\mathrm{w}$ dramacie świata. Znamienne, że praktycznie wszyscy bohaterowie mają swoje chwile szczerości, podczas których ujawniają, „co im w duszy gra". Autorefleksyjność, charakterystyczna dla bohaterów monodramów Griszkowca, również w tej sztuce staje się istotnym elementem kreacji postaci ${ }^{39}$.

W Oblężeniu splatają się niezwykle ważne dla Jewgienija Griszkowca zagadnienia, powracające natrętnie $\mathrm{w}$ wielu jego sztukach: człowiek wobec doświadczenia wojny, refleksja nad naturą czasu oraz niemożność autentycznego porozumienia, „komunikacyjna nieefektywność” współczesnego świata ${ }^{40}$. Badacze, pisząc o problematyce tego dramatu, na pierwszym miejscu umieszczają zazwyczaj temat wojny, eksponując ponadczasowość tego tematu, jego rangę i znaczenie w kulturze rosyjskiej, ale też sposób ujęcia (strategia gry) i osobiste zaangażowanie autora:

„Осада" - спектакль о войне, [...] о войне вообще $[. . .]^{41}$,

[Oblężenie - spektakl o wojnie, [...] o wojnie jako takiej].

„Осада" - спектакль о войне, а точнее, об игре в войну42.

[Oblężenie - spektakl o wojnie, a precyzyjniej, o grze w wojnę].

\footnotetext{
39 Tę cechę postaci kreowanych przez Griszkowca Dmitrij Bykow wiąże z psychoterapeutyczną funkcją jego teatru. Zob. D. Bykov, Vzroslaâ žizn' molodogo čeloveka, [dostęp 7.03.2018].

40 Zob. np. T.N.Breeva, Značenie kommunikativnogo provala v p'esah E. Griškovca, w: Sovremennâ̂ rossijskâ̂ drama: materialy meždunar. nauč. konf., 27-29 sent. 2007 g., Kazan' 2008, s. 84-91.

41 M. I. Gromova, Russkâ̂ dramaturgiâ konca XX - načalo XXI vv..., s. 357.

42 M. Lipoveckij, B. Bojmers, Performansy nasiliâ..., s. 155.
} 
В „Осаде” Гришковец затронет одну из стержневых ценностей страны: отношение к войне. Это тема [...] очень личная для автора ${ }^{43}$.

[W Oblężeniu Griszkowiec poruszy jedną z kluczowych wartości narodu: stosunek do wojny. Jest to temat [...] dla autora bardzo osobisty].

Widz zostaje wrzucony $\mathrm{w}$ świat dramatu in medias res - w bliżej nieokreślony moment snucia opowieści przez Weterana. Sytuacja komunikacyjna w punkcie wyjścia ustanawia złożoną przestrzeń interakcji pomiędzy jej uczestnikami: „opowiadacz” - „słuchacz”, ,,żołnierz” - „cywil”, ,dojrzałość" - „młodość”, ,przeszłość” - „teraźniejszość”, „starożytność” - „współczesność". Nie wiemy, jak doszło do spotkania i dokąd zmierzają bohaterowie. Od samego początku jednak ważnymi składowymi ich interakcji są: konsekwentne dążenie Weterana, aby „właściwe dać rzeczy słowo” [„Старый же такой человек, а не дедушка. Я же тебе точные термины говорю!". „Stary taki człowiek, a nie dziadek. Przecież dokładne terminy ci mówię!", s. 100], poczucie rangi przywoływanych historii [„Таких историй тебе никто не расскажет”. „Tаkich historii nikt ci nie opowie”, s. 97; „Я важную историю рассказываю”. „Ważną historię opowiadam”, s. 100], "głuchota” Chłopaka [„,Ты слушаешь, но не слышышь”. „Słuchasz, ale nie słyszysz", s. 97].

Doświadczony żołnierz próbuje opowiedzieć napotkanemu młodemu mężczyźnie, który „prochu nie wąchał”, czym jest wojna i zderzenie młodzieńczych wyobrażeń o walce z rzeczywistością pierwszego boju (śmiercią, "strachem, brudem i zagubieniem"), w jaki sposób człowiek powoli przyzwyczaja się do wojennego chaosu, jak wygląda codzienne żołnierskie życie, o czym nigdy nie wolno zapomnieć żołnierzowi, jeśli chce przetrwać, co daje siłę w walce i zapewnia zwycięstwo itd. W wypowiedzi Weterana pojawia się też motyw oblężenia jako niezwykle istotne doświadczenie - cezura, która podzieliła jego życie na to, co było przedtem i to, co zdarzyło się później [,Но та последняя осада! Она просто поделила все на то, что была до, и то, что было потом”. „О, ta ostatnia osada! Ona zwyczajnie podzieliła wszystko na przedtem i potem", s. 93].

Motyw ten, obecny (bezpośrednio bądź pośrednio) na przestrzeni całego dramatu, będzie powoli obrastał znaczeniami, stając się fabularną, egzystencjalną i symboliczną klamrą wszystkich jego wątków.

W wypowiedzi doświadczonego wojaka odnajdziemy też cały zestaw stereotypów związanych np. z sielskim obrazem wsi, idealizacją przeszłości czy z wizerunkiem „prawdziwego mężczyzny” - obrońcy, który powi-

43 V. Gudkova, Teatr i mneniâ Evgeniâ Griškovca, s. 71. 
nien być zawsze gotowy, aby wypełnić swoje przeznaczenie [„,Ты же мужчина и должен быть зашитником”. „Przecież jesteś mężczyzną i powinieneś byś obrońcą", s. 92]. Obok historii opisujących codzienność wojny, zwykły żołnierski byt (rozpoznanie terenu, nawiązanie kontaktu z ludnością miejscową, umiejętność przetrwania $\mathrm{w}$ trudnych, polowych warunkach) pojawiają się „ważne opowieści”, w których stopniowo rozpoznajemy powszechnie znane mity, ukazujące różne przejawy bohaterstwa/heroizmu: „B «Осаде» Гришковец разыгривает комическую деконструкцию героического мифа [...]"44.

Jednak komizm w przypadku wątku Weterana i Chłopaka to dla Griszkowca zaledwie punkt wyjścia - pierwszy etap owej dekonstrukcji. Rzeczywiście, subiektywny przekaz Weterana - świadka i uczestnika wydarzeń reaktywujący pierwotną formę funkcjonowania mitu (opowieść ustna) zdaje się trywializować, „odbrązawiać” obraz mitycznych bohaterów. Zarówno mit o jednej z dziesięciu prac Herkulesa (praca szósta - oczyszczenie stajni Augiasza), jak i mit o Syzyfie zostają przeniesione $\mathrm{w}$ wojenne realia. $\mathrm{W}$ opowieści Weterana Herkules jest jednym z żołnierzy w jego oddziale - „ogromnym, krzepkim, po męsku pięknym”, „rosłym chłopakiem, który źle rozmawia” [„здоровый парень, который плохо розговаривает", s. 101]. Nie wiadomo, z jakiego powodu potrafi on wydawać jedynie niezrozumiałe dźwięki, przypominające gaworzenie dziecka [„,бу-бу-бу, бу-бу-бy", s. 97], przez które towarzysze broni nadali mu imię Bubniła (Бубнила). Znamienne, że ten defekt wcale nie utrudnia bohaterowi komunikacji z pozostałymi członkami oddziału, a groteskowy obraz mitycznego herosa, w którym siła zderza się ze słabością, a doskonałość ze skazą, przewartościowuje pojmowanie prawdziwego bohaterstwa. W postaci Bubniły piękno zewnętrzne łączy się bowiem z pięknem wewnętrznym, "mądrością serca", co wywołuje zachwyt i uznanie opowiadacza:

Вот какой человек! Умный! [...] Аобрый! [...] Скромный!, [s. 104].

[Co za człowiek! Mądry! [...] Dobry! [...] Skromny!]

Czyn, którego dokonuje bohater opowieści Weterana, jest bowiem aktem bezinteresownym, wypływającym z potrzeby serca, a nie dla sławy i poklasku. Towarzysze nigdy nie dowiedzieliby się o dokonaniu Bubniły (Herkulesa), gdyby nie potrzeba starego człowieka (Augiasza) odwdzięczenia się za pomoc:

44 „W Oblężeniu Griszkowiec rozgrywa komiczną dekonstrukcję heroicznego mitu” [M. Lipoveckij, B. Bojmers, Performansy nasiliâ..., s. 154]. 
Мы то с дедом поссорились и ушли. А он-то видел, что человек старый и одинокий. Помог человеку, [s. 104].

[My to ze starcem pokłóciliśmy się i odeszliśmy. A on żeż widział, że człowiek stary i samotny. Pomógł człowiekowi].

Paradoksalnie, werbalna ułomność Bubniły daje mu przewagę nad pozostałymi. Jego historia ilustruje wyższość komunikacji niewerbalnej, posiłkującej się empatią i głębokim zrozumieniem sytuacji drugiego człowieka. Zdaje się być jednym ze sposobów wyjścia z impasu "zamknięcia w określonym dyskursie". Weteran i jego towarzysze nie potrafili obejść tej pułapki języka. Przypomnijmy, jak Griszkowiec ilustruje zapętlenie się (do granic absurdu) dialogu pomiędzy Weteranem (Odyseuszem) a właścicielem stajni (Augiaszem):

я говорю: „[...] Тут надо три дня и три раза больше народа, у нас времени нет, ты нам еду не готовь, мы пойдем”. А он говорит: „А я вам тогда не буду еду готовить, если вы не будете работать”. А я ему отвечаю: „Наоборот, дед, это мы тебе помогать не будем, поэтому нам не надо готовить”. А он свое: „Тогда я вам не буду готовить, если вы не будете помогать”. Я к нему подошел и говорю ему: „Ты не понял, дед! Это мы тебе помогать не будем, поэтому не надо...". В общем, поссорились мы с этим дедом, [s. 102].

[mówię: „,...] Tu potrzeba trzech dni i trzy razy więcej ludzi, nie mamy czasu, ty nam jedzenia nie przygotowuj, my pójdziemy”. A on mówi: „W takim razie, nie będę przygotowywał wam jedzenia, skoro nie będziecie pracować”. A ja mu na to odpowiadam: "Na odwrót, starcze, to my nie będziemy ci pomagać, dlatego nie ma potrzeby nam przygotowywać”. A on swoje: „Więc nie będę wam przygotowywał, jeśli wy nie będziecie pomagać". Podszedłem do niego i mówię mu: „Nie zrozumiałeś, starcze! To my nie będziemy ci pomagać, dlatego nie ma potrzeby...". W sumie, pokłóciliśmy się z tym starcem].

Każdy z uczestników „rozmowy” jest przekonany, że to jego wypowiedź najlepiej opisuje sytuację. Powtarzające się, z nieistotnymi semantycznie modyfikacjami, sformułowania ukazują całkowicie odmienne punkty widzenia - sposoby odbioru tego samego wydarzenia. Subiektywizacja eksponuje względność samego "faktu”, a co za tym idzie - rzeczywistości i jednej "prawdy”, a reprodukowane konsekwentnie frazy „zamykają" w swoim obrębie bohaterów, uniemożliwiając jakikolwiek dialog.

Z kolei Syzyf w opowieści Weterana zostaje ukazany jako „miejscowy cudak", którego opowiadacz spotyka w pewnej wsi podczas działań wojennych. „Wiejski dziwak” prezentuje zachowanie niezrozumiałe dla pozostałych mieszkańców. Z własnej woli od wielu lat konsekwentnie powtarza ten sam, absurdalny dla członków społeczności, w której funkcjonuje, „rytuał" - bezskutecznie próbuje wtoczyć na górę ogromny głaz [„„Необычный 
камень, почти круглый”. „Niezwykły kamień, prawie okrągły”, s. 124]. Opuszczony przez bliskich uporczywie kontynuuje swoje dzieło, niezrażony ciągłym niepowodzeniem. Samotny trud Syzyfa nie jest karą zesłaną przez rozgniewanych bogów, tylko świadomym wyborem - działaniem, które nadaje sens jego istnieniu ${ }^{45}$. Weteran eksponuje jednak inny aspekt tej historii. Otóż poczynania pijanych towarzyszy Odyseusza, którzy zdecydowali się pomóc biednemu dziwakowi i, podczas jego nieobecności, wtoczyli kamień na górę, burzą jego świat:

\begin{abstract}
„вижу, что ты обиделся. Аавай мы этот камень обратно скатим, и толкай его себе на здоровье”. А он подумал и говорит: „Аа нет, не надо. Теперь уже не то". А я ему: „Чего не то-то? Гора та же, камень тот же, ты тот же. Сейчас пойдем и вернем твой камень на место". А он остановил меня, [...] грустно посмотрел в глаза и говорит: „Теперь, - говорит, - уже не то”. В общем, смысл такой: жизнь мы этому мужику поломали, понимаешь, [s. 128].

[„,widzę, że się obraziłeś. Chodźmy, stoczmy ten kamień z powrotem i wtaczaj go sobie na zdrowie”. A on pomyślał i mówi: „Ależ nie, nie trzeba. Teraz to już nie to". A ja mu: „Czemuż to nie to? Góra ta sama, kamień tenże, ty też ten sam. Zaraz pójdziemy i zwrócimy twój kamień na miejsce". A on zatrzymał mnie, [...] smutno popatrzył w oczy i mówi: „Teraz, - mówi, - już nie to”. Ogólnie, sens taki: życie my temu facetowi złamaliśmy, rozumiesz].
\end{abstract}

Opowieść mityczna w interpretacji Weterana staje się częścią jego życiowego doświadczenia, ilustracją elementarnej na pozór prawdy, że trudno zrozumieć drugiego człowieka i z jak dużą ostrożnością należy podejmować decyzję o ingerowaniu w jego życie. Jednocześnie, biorąc pod uwagę złożoność kreacji opowiadacza, historie o Herkulesie i Syzyfie można potraktować jako jedne z licznych przygód tułacza Odyseusza.

Niestety, prawda o człowieku, którą chce przekazać Chłopakowi Weteran poprzez swoje „ważne” opowieści, pozostaje niezrozumiana i „nieusłyszana". Komentując te historie młody człowiek stwierdza wprost:

Бред какой-то. [...] Я не очень понял, что он мне рассказывал... [...]. Врет мне этот мужик, [s. 120-121].

[Jakieś brednie. [...] Nie za bardzo zrozumiałem, co on mi opowiadał... [...]. Ten facet mnie okłamuje].

Chłopak odbiera je powierzchownie, zatrzymuje się bowiem na zdarzeniowej, fabularnej warstwie trywializując jej treści. Stąd też "przygody”

45 Por. egzystencjalną interpretację mitu o Syzyfie A. Camus, Mit Syzyfa w: tegoż, Eseje, wybór i przekład J. Guze, Warszawa 1971. 
Odyseusza są dla niego niedorzeczne - mit traci rangę nośnika wiedzy o świecie, swoją epistemologiczną i dydaktyczną funkcję. Jeżeli przyjmiemy, że w dramacie postać Chłopaka staje się reprezentacją młodego pokolenia, to fakt, że nie potrafi on przypomnieć sobie, skąd zna opowiadane przez Weterana/Odyseusza historie, ilustruje stan kulturowej „amnezji” pokolenia cyfrowej komunikacji, a sam charakter relacji pomiędzy bohaterami - powierzchowność i konwencjonalność kontaktu teraźniejszości z przeszłością, współczesności z wielką tradycją antyku. Odyseusz bezskutecznie stara się dotrzeć do Chłopaka - świadomy wyjątkowości swoich mądrościowych narracji [„Я же [...] свои лучшие истории рассказал. [...] Ему такого никто не расскажет”. „Przecież [...] opowiedziałem mu swoje najlepsze historie. [...] Nikt mu takich nie opowie", s. 140], pragnie przekazać mu wiedzę i doświadczenie, chociaż zdaje sobie doskonale sprawę, że ten ostatni nie dostrzega w nim Mistrza i nie jest zainteresowany rolą „pilnego ucznia”. Z kolei Chłopakowi, niecierpliwie zerkającemu na telefon komórkowy lub próbującemu dyskretnie przesyłać wiadomości SMS, dobre wychowanie nie pozwala przerwać rozmowy i odejść. Paradoksalnie, to właśnie jego hiperpoprawność wprowadza fałsz w ich wzajemne relacje, skazując je na nieautentyczność. Młody człowiek posuwa się bowiem do kłamstwa, twierdząc, że opowieści Weterana mu się podobają, i prosi o kolejne. W efekcie obaj są coraz bardziej zniechęceni i zmęczeni „rozmową”, której stają się mimowolnymi „więźniami”. Odyseusz podejmuje jeszcze desperacką próbę opowiedzenia "najdłuższej historii", by po chwili zrezygnować. Rozczarowany "głuchotą" i „niepamięcią" Chłopaka oraz tym, że mimo jego heroicznych czynów świat nie zmienił się na lepsze, ale pozostał "normalny”, zaczyna wątpić w sens zwycięstwa pod Troją. Dręczy go świadomość, że to on wymyślił sposób na pokonanie przeciwnika. Odyseusz nie chce się pogodzić z rutyną istnienia banalną, byle jaką „normalnością" - i odchodzi:

я не думал, что так будет... Что не с кем будет поговорить. Что будет вот так все, как ты сказал, „нормально”. Когда была это осада, было плохо, а мы хотели чтобы было хорошо. А теперь „нормально”. Вот и сиди здесь, и живи „нормально”... [s. 157].

[nie myślałem, że tak będzie... Że nie będzie z kim porozmawiać. Że wszystko będzie tak, jak powiedziałeś, „normalnie”. Kiedy było to oblężenie, było źle, i chcieliśmy, żeby było dobrze, A teraz jest „normalnie”. No to siedź tutaj i żyj „,normalnie”...].

Krach referencyjnej funkcji języka zostaje w sztuce Griszkowca obnażony ze szczególną siłą poprzez wątek fabularny związany z trzema wojownikami oblegającymi Troję. Rozwijając się równolegle do historii Weterana i Chło- 
paka prezentuje on "binarne” zderzenie dyskursów - dyskursu przemocy (wojny) i dyskursu porozumienia (pokoju). Bohaterów spotykamy w momencie, gdy jeden z nich błaga pozostałych, aby go wysłuchali. Trzeci wojownik (Achilles) nie jest w stanie dłużej znosić zaistniałej sytuacji: trwających od wielu lat bezskutecznych prób zdobycia miasta, codziennej utraty przyjaciół i towarzyszy broni, bezcelowych śmierci „najlepszych z najlepszych”. Jako jedyny ma odwagę spojrzeć prawdzie w oczy i nazwać rzeczy po imieniu:

Никто уже не помнит, по какой причине мы приплыли сюда и стоим под этими стенами, [s. 105] ${ }^{46}$.

[Nikt już nie pamięta, z jakiego powodu przypłynęliśmy tutaj i stoimy pod tymi ścianami].

Wojna trwa tak długo, że nikt już nie pamięta, z jakiego powodu wybuchła i jaki jest jej cel. Obnażając absurdalność niekończącej się walki, bohater przekonuje o konieczności rozpoczęcia rozmów pokojowych:

Третий воин. [...] Мы должны попробовать начать договариваться.

Первый воин. Чего попробовать начать?

Третий вотн. Попробовать вступить в мирный диалог.

Первый воин. Куда попробовать вступить?

Третий вотн. Иницировать переговоры.

Первый воин. Чего сделать?

Третий воин. Иници... Ну то есть начать переговоры, [s. 105].

[Trzeci wojownik: Powinniśmy spróbować zacząć dogadywać się.

Pierwszy wojownik: Co spróbować zacząć?

Trzeci wojownik: Spróbować wejść w pokojowy dialog.

Pierwszy wojownik: Gdzie spróbować wejść?

Trzeci wojownik: Zainicjować rozmowy.

Pierwszy wojownik: Czego zrobić?

Trzeci wojownik: Zaini... No, to znaczy rozpocząć rozmowy].

Achilles Griszkowca jest intelektualistą, myślicielem, najbardziej refleksyjnym z trójki wojowników. Przytoczony dialog pokazuje, że, w przeciwieństwie do swoich współrozmówców, posługuje się językiem wyszukanym, nasyconym wyrażeniami książkowymi i słowami obcego pochodzenia. Aby dotrzeć do pozostałych, mnoży określenia synonimiczne. W niecytowanej części rozmowy opisuje zaistniałą sytuację jako „patową" („патовая”),

\footnotetext{
46 Por. I. Brodskij, Odisej Telemaku, w: tegoż, Sočineniâ Iosifa Brodskogo, t. 3, Sankt-Petersburg
} 1998, s. 27. 
„bez wyjścia” („безвыходная”), „nierozstrzygalną" („безысходная”). Wprowadza także określenia, które „rozmywają”, łagodzą ostrość konfliktu, zaczynając funkcjonować jak eufemizmy - słowo „wrogowie” („враги”) рroponuje na przykład zamienić na słowa „rywale” („соперники”) lub „ороzусја” („оппозиция"):

Первый воин. Ну с кем вести переговоры?! С кем?!

Третий воин. (делает жест в сторону зрительного зала). С ними, с кем еще?

Первый воин. С кем, с ними? С врагами нашими, что ли? [...]

Третий воин. Ну-у-у... С соперниками... С оппозицией [s. 105-106].

[Pierwszy wojownik: No, z kim prowadzić rozmowy?! Z kim?!

Trzeci wojownik: (wykonuje gest w stronę widowni). Z nimi, z kimże jeszcze?

Pierwszy wojownik: $Z$ kim, z nimi? Z naszymi wrogami, tak?

Trzeci wojownik: No-o-o... Z rywalami... Z opozycją].

Powyższy fragment ukazuje również kolejne znaczenie motywu oblężenia w dramacie Jewgienija Griszkowca. W momencie bowiem, gdy za pomocą chwytów metatekstowych widz zostaje włączony w fabularną i semantyczną przestrzeń tekstu, relacja "oblegający” - „oblegani” zaczyna oznaczać także relację "sztuka” - „odbiorca”. Zatem podejmowane przez Trzeciego wojownika próby przewartościowania charakteru tej zależności mogą być postrzegane jako postulat odejścia od sztuki narzucającej gotowe schematy myślowe (traktującej widza jak „wroga”, którego trzeba „zdobyć”, tzn. podporządkować sobie) w stronę sztuki podejmującej dialog, proponującej wspólne poszukiwanie prawdy.

Działania Trzeciego wojownika ilustrują, że język nigdy nie jest po prostu „przezroczystym”, neutralnym narzędziem komunikacji, ale staje się „kreatorem” rzeczywistości, ponieważ sam sposób opisu zdarzenia wpływa na nie - stanowi jego interpretację. Propozycja Achillesa, aby standardowo rozumiane "ostateczne zwycięstwo" (zniszczyć mur, rzucić wszystkich na kolana, przemaszerować główną ulicą, wciągnąć swoją flagę na maszt) zastąpić „innym zwycięstwem” spotyka się ze zdecydowanym sprzeciwem pozostałych wojowników, nie potrafiących wyjść poza określające ich kondycję „żołnierza-bohatera" schematy myślowe i kondensujące ich znaczenie symbole kulturowe. Trzeci wojownik buntuje się przeciwko ograniczającej, despotycznej władzy dyskursu "starych, zaskorupiałych symboli" [„старые заскорузлые символы”, s. 107], które uważa za anachroniczne w zaistniałej sytuacji. Pozostali, oburzeni "szarganiem świętości” (Achilles nazywa flagę "szmatką na patyku") bronią znaczenia narodowych symboli: 
Первый воин. [...] нам нужны символы, народу нашему нужны символы! [s. 107-108].

[Pierwszy wojownik: [...] potrzebujemy symboli, nasz naród potrzebuje symboli!]

Griszkowiec aktualizuje zatem zarówno konstruktywną (konsolidującą), jak i destrukcyjną (zamykającą) naturę kulturowych symboli. Desperackie próby nauczenia towarzyszy broni nowego, pokojowego dyskursu opartego na tolerancji, wartościach humanistycznych, tzn. skłonienia ich do rozmów z mieszkańcami Troi, kończą się fiaskiem. Co prawda wojownicy podejmują (pod dyktando Achillesa) dialog z oblężonymi, szybko jednak przeradza się on w parodię, stając się groteskową manifestacją siły i zapowiedzią wojennego okrucieństwa oblegających. Nie potrafią oni bowiem przyjąć proponowanego przez Achillesa dyskursu (światopoglądu), ani też zdystansować się wobec własnego. Nie są zdolni do przewartościowania swego sposobu widzenia rzeczywistości. Sytuację, w której tkwią, postrzegają bowiem w kategoriach obowiązku, długu wobec narodu, co stanowi ważny element ich autoidentyfikacji:

Второй воин. Вот нас сюда народ послал... [...] А народ у нас за спиной, и мы стоим здесь и должны стоять. [...] Мы плоть от плоти, кровь от крови народа! [s. 109].

[Drugi wojownik: Oto nas tutaj naród posłał... [...] A naród mamy za plecami i stoimy tutaj, i powinniśmy stać. [...] My ciało z ciała, krew z krwi narodu!]

Niemożność wyzwolenia się z dyskursu narzucającego określony obraz świata (języka kulturowych symboli) eksponują w tekście dramatu także liczne gry językowe, wykorzystujące m.in. chwyt paronomazji: „анахронизм" ('anachronizm') - „анна...хренизм” ('anna...chrzanizm') - „на-хронизм" ("na-chronizm') [s. 107-108, 110], „пенять на народ" ('mieć pretensję do narodu') - „пинать народ” ('kopać/walić naród'), [s. 109], „юродствует” ('zachowuje się jak jurodiwy') - „уродствуешь” ('zachowujesz się jak wyrodek') [s. 110-111], „кровь” ('krew') - „ккров” ('dom', 'schronienie') [s. 116], „катастрофическое” ('katastroficzne') - „кастрата...” ('kastrata...') - „контраса...” ('kontrasa...') - „кастра...” ('kastra...'), [s. 113]. Przypomina to efekt "głuchego telefonu", tworząc groteskową oprawę wszystkich narracji/zdarzeń i rzucając komiczno-ironiczne światło na dramat „zamknięcia w języku". Towarzysze broni, nie rozumiejąc Achillesa, powtarzają jego słowa tak, jak potrafią: zastępują znanymi sobie, podobnie brzmiącymi wyrazami, przekręcają je, tworzą nowe. Jego zapewnienia, że aby dotrzeć do oblężonych, 
aby zostać usłyszanym, trzeba dążyć do konsensusu, odrzucając bezapelacyjne stwierdzenia, pozostają bez odzewu. Niepowodzeniem kończy się odważna próba przewartościowania tradycyjnych, warunkowanych kulturowo stereotypów myślenia, reakcji i sposobów postępowania - próba zastąpienia imperatywu „muszę/powinienem" imperatywem „myślę". Wątek trzech wojowników oblegających Troję urywa się w pół słowa, kiedy Achilles próbuje wyjaśnić pozostałym (znowu bez powodzenia), czym jest $w$ istocie jego dar - „pięta Achillesa". Jego inność i wyjątkowość niepokoi, wywołuje podejrzenia i różne spekulacje. W ostatnim momencie Achilles cofa nogę, przerywając $\mathrm{w}$ ten sposób wymuszony na nim absurdalny eksperyment, który miał sprawdzić, czy można go zabić, a tym samym „udowodnić” jego zwyczajność bądź cudowność.

Ostatnie słowa w dramacie Griszkowca należą do Chłopaka, przytaczającego usłyszaną w radiu historię o wyczynie braci Wright, którzy w 1903 roku jako pierwsi dokonali udanego przelotu płatowcem wyposażonym w silnik. Z perspektywy czytelnika i widza finałowa opowieść mogłaby stać się nie tylko budującą puentą (napisaną przez rzeczywistość) wysiłków Ikara, dowodem na to, że człowiek może pokonać własne ograniczenia, ale i spotkaniem prawdy „mitycznej opowieści” z prawdą „realnych wydarzeń” (prawdą życia), dialogiem między przeszłością a współczesnością. Mogłaby, gdyby Chłopak rozumiał, po co opowiada tę historię („А зачем я вам это сказал, не знаю” - „Pо со wam to powiedziałem, nie wiem”, [s. 158]), a nie po prostu przekazywał dalej zasłyszane informacje... Opowieść Chłopaka daleka jest także od historycznej ścisłości, twierdzi on na przykład, że to właśnie w 1903 roku człowiek po raz pierwszy oderwał się od ziemi, ignorując zupełnie wcześniejsze fakty dotyczące rozwoju aeronautyki, takie np. jak udane loty balonem oraz próby z szybowcami. Właściwie nierozstrzygalna pozostaje kwestia, czy jest to efekt nierzetelnie przygotowanej informacji radiowej, czy transformacja przekazu na poziomie odbioru. Pozostaje gorzki posmak dewaluacji słowa. Skierowana do widzów „opowieść” bohatera staje się bowiem przewrotną egzemplifikacją sposobu funkcjonowania opowieści we współczesnym świecie, w którym często stają się one po prostu bezrefleksyjnie powielanymi interesującymi „historyjkami”. Podsumowując, należy zauważyć, że kluczowy dla dramatu Griszkowca motyw oblężenia, wprowadzony już $\mathrm{w}$ samym tytule utworu, staje się pojemną formułą, pozwalającą autorowi artykułować określone sensy na różnych poziomach dzieła. Oblężenie w sztuce Jewgienija Griszkowca to nie tylko określona sytuacja na wojnie, intertekstualna gra z Illiadq Homera (reinterpretacja historii oblegania Troi), metafora „zamknięcia” w języku jako takim (lub w określonym, warunkowanym kulturowo dyskursie), istotne 
przeżycie egzystencjalne („graniczne” doświadczenie w życiu bohaterów), ale również refleksja nad różnymi modelami sztuki, w szczególności sztuki dramatycznej.

\section{Bibliografia}

Abaulin Dmitrij (2002), Griszkowiec ante portas, „Dialog”, nr 5-6, s. 220-221.

Bolotân Il'mira (2006), Griškovec: avtor, fenomen, sindrom, „Literaturnaâ Rossiâ”, nr 42, https://litrossia.ru/item/1263-oldarchive.

Breeva Tat'âna Nikolaevna (2008), Značenie kommunikationogo provala v p'esah E. Griškovca, w: Sovremennaâ rossijskaâ drama: materialy meždunar. nauč. konf., 27-29 sent. 2007 g., Kazan', s. 84-91.

Brodskij Iosif (1998), Odisej Telemaku, w: I. Brodskij, Sočineniâ Iosifa Brodskogo, t. 3, Sankt-Petersburg: Izdatel'stvo „Puškinskij fond”.

Bykov Dmitrij (2002), Vzroslaâ žizn' molodogo čeloveka, „Novyj mir”, nr 1, https://ma gazines.gorky.media/novyi_mi/2002/1/vzroslaya-zhizn-molodogo-cheloveka. html.

Camus Albert (1971), Mit Syzyfa w: A. Camus, Eseje, wybór i przeł. J. Guze, Warszawa: Państwowy Instytut Wydawniczy.

Davydova Marina (2005), Konec teatral'noj èpohi, Moskva: Izdatel'stvo OGI.

Evrosinin Stas, Aktual'noe odinočestvo Evgeniâ Griškovca, „Novyj mir” 2006, nr 11, https://magazines.gorky.media/novyi_mi/2006/11/aktualnoe-odinochestvo-ev geniya-grishkovcza.html.

Gončarova-Grabovskaâ Svetlana (2009), Monodrama v tvorčestve E. Grǐ̌kovca, „Vesnìk BDU", seria 4, nr 3, s. 26-31.

Gracla Jadwiga (2017), Jewgienij Griszkowiec: autor, aktor, twórca, w: Artysta. Biokulturowy interfejs?, red. M. Pieniążek, Kraków: Wydawnictwo Edukacyjne, s. 56-65.

Griškovec Evgenij (2011), Satisfakciâ. Scenarij, p'esyi lirika, Moskva: Mahaon, Azbuka-Att.

Gromova Margarita Ivanovna (2009), Russkaâ dramaturgiâ konca XX - načalo XXI vv., Moskva: Flinta.

Grotowski Jerzy (2012), Teatr a rytuał, w: J. Grotowski, Teksty zebrane, red. A. Adamiecka-Sitek i in., Warszawa: Wydawnictwo Krytyki Politycznej, Instytut im. Jerzego Grotowskiego, Instytut Teatralny im. Zbigniewa Raszewskiego, s. 356-373.

Gudkova Violetta (2007), Teatr i mneniâ Evgeniâ Griškovca, w: Pro scenium. Voprosy teatra, izd. vtoroe, ispr., sost. i otv. red. V.A. Maksimova, Moskva, s. 58-75.

Lipoveckij Mark, Bojmers Birgit (2008), Travma - performans - identičnost': intimnyj teatr Evgeniâ Griškovca, w: SSSR: territoriâ lübvi. Sbornik statej. (Novye materialy i issledovaniâ po istoriirusskoj kul'tury. Vyp. 6), red.-sost. N. Borisova, K. Bogdanov, Û. Murašov, Moskva: Novoe izdatel'stvo, s. 233-267. 
Lipoveckij Mark, Bojmers Birgit (2012), Performansy nasiliâ: literaturnye i teatral'nye èksperimenty "novoj dramy”, Moskva: Novoe literaturnoe obozrenie.

Maciejewski Łukasz, Śmiesznie i strasznie bywa w teatrze Bagatela, "Gazeta Krakowska” 30 listopada 2011, http://www.dziennikteatralny.pl/artykuly/smiesznie-i-strasz nie-bywa-w-teatrze-bagatela.html.

Mazurek Halina (2015), Oblicza monodramu w nowej dramaturgii rosyjskiej, „Studia Słowianoznawcze" , t. 11, s. 223-242.

Michalski Yan, Grotowski - mnich poszukiwań teatralnych, http://www.grotowski.net/ performer/performer-6/grotowski-mnich-poszukiwan-teatralnych.

Mięsowska Lidia (2004), Jewgienij Griszkowiec "nowy sentymentalista" rosyjskiej dramaturgii przełomu XX $i$ XXI wieku, w: Tradycje $i$ nowatorstwo w kulturach i literaturach słowiańskich, red. I. Kowalska-Paszt i in., Szczecin: Uniwersytet Szczeciński, s. $118-126$.

Mięsowska Lidia (2016), Między postkomunizmem a postmodernizmem. Najnowszy dramat rosyjski w poszukiwaniu tożsamości kulturowej, „Miscellanea Posttotalitariana Wratislaviensia", nr 4, s. 59-77.

Naumova Ol'ga Sergeevna (2008), Problema teatral'nogo sinkretizma v tvorčestve E. Griškovca, w: Sovremennaâ rossijskâ̂ drama: materialy meždunar. nauč. konf., 27-29 sent. 2007 g., Kazan': Škola.

Naumova Ol'ga Sergeevna (2018), Obraz čeloveka v hudožestvennoj literature konca XX - načala XXI vv., Samara: Samar. gos. tehn. un-t.

NDiaye Iwona Anna (2016), O specyfice kulturowo-językowej monodramu Jewgienija Griszkowca "Jak zjadłem psa" i potencjalnych oraz realnych reperkusjach przekładowych z uwzględnieniem tłumaczenia na język polski, „Acta Neophilologica” t. 18, nr 2, s. 161-177.

Piłat Walenty (2001), Jewogienij Griszkowiec - dramaturg, reżyser czy twórca spektaklu. „Przegląd Rusycystyczny”, z. 2, s. 68-74.

Piłat Walenty (2005), Teatr "nowego sentymentalizmu” Jewginija Griszkowca i jego polskie interpretacje, "Acta Polono-Ruthenica", t. 10; s. 199-203.

Piłat Walenty (2015), Monodram we wspótczesnej dramaturgii rosyjskiej, „Acta Neophilologica", t. 17, nr 1, s. 145-152.

Rudnev Pavel (2018), Drama pamâti. Očerki istorii rossijskoj dramaturgii. 1950-2010-oe, Moskva: Novoe literaturnoe obozrenie.

Ruta-Rutkowska Krystyna (2000), Metateatralne gry w dramacie współczesnym na przykładzie twórczości Mariana Pankowskiego, „Pamiętnik Literacki”, z. 4., s. 125-153.

Syska Katarzyna (2013), Nowa sentymentalność. Przejawy świadomości konwergencyjnej w wybranych monodramach Jewgienija Griszkowca, "Przegląd Rusycystyczny", nr 2, s. $56-82$.

Wittgenstein Ludwig (2000), Tractatus logico-philosophicus, przeł. i wstępem opatrzył B. Wolniewicz, Warszawa: Wydawnictwo Naukowe PWN. 


\title{
Enclosed in Language: The Siege by Evgeny Grishkovets
}

\begin{abstract}
The author of this article analyzes the play The Siege by Evgeny Grishkovets, a renowned contemporary Russian writer. She places it against a background of the rest of his works, exposing essential features that characterize his entire dramaturgy, such as the presence of metatheatrical devices, recognition of the importance of contact with the audience, and emphasis on stage performance. The analysis also draws attention to such elements of the play as non-homogeneous spatio-temoral framework, hybrid composition of characters, and parallel development of plot threads. Special attention is paid to the "imprisoning" of characters in discourses and the ambivalent nature of cultural symbols. As the author points out, the Siege stands out in the Grishkovets's oeuvre, both by departing from the dominant monodrama form and by juxtaposing key themes recurring in his works: the human experience of war, the reflection on the nature of time, the collapse of language referential abilities, and the impossibility of authentic communication.
\end{abstract}

Keywords: contemporary Russian drama, postmodernism, intertextuality, myth 